\title{
Pengaruh Lingkungan Kerja Terhadap Kinerja Karyawan Pada PT. Pos Indonesia Depok
}

\author{
Komarudin \\ Dosen Fakultas Ekonomi Universitas Pamulang \\ Email : komarudin_101263@yahoo.com
}

\begin{abstract}
ABSTRAK
Tujuan penelitian ini adalah Untuk mengetahui Lingkungan kerja PT Pos Indonesia Depok, Untuk mengetahui Kinerja karyawan PT Pos Indonesia Depok dan Untuk mengetahui Pengaruh Lingkungan Kerja terhadap Kinerja Karyawan PT Pos Indonesia Depok

Metodologi penelitian analisa kuantitatif sifat studi kasus dengan menggunakan data bersifat deskriptif kuantitatif. Metodologi dalam penelitian ini adalah analisis kuantitatif dengan sifat deskripsi kuantitatif. Sedangkan Populasi dalam penelitian ini adalah seluruh karyawaPT Pos Indonesia Depok yang berjumlah 56 orang. penulis menetapkan populasi sampel dalam penelitian ini adalah semuanya sebagai sampel yaitu 56 orang. karena dalam penelitian populasinya kurang dari 100 maka sampel yang di ambil adalah sampel jenuh/sensus. Meliputi observasi,wawancara dan kuesioner.

Hasil penelitian dapat di lihat dari metode pengambilan data. Uji Reliabilitas, berdasarkan hasil perhitungan instrumen variabel Lingkungan Kerja Terhadap Kinerja lebih besar dari rtabel yaitu 0,895> 0,279 sehingga instrumen penelitian dapat dikatakan reliabel.Uji Korelasi, berdasarkan hasil perhitungan korelasi product moment didapat nilai $\mathrm{r}_{\mathrm{xy}}$ sebesar 0,986 yang artinya terdapat hubungan positif yang kuat antara lingkungan kerja terhadap kinerja karyawan.Uji Regresi Linier Sederhana, berdasarkan perhitungan didapat nilai koefisien regresi variabel Lingkungan Kerja (X) terhadap Kinerja Karyawan (Y) adalah sebesar 1,107.Uji koefisien Determinasi, berdasarkan perhitungan kontribusi variabel Lingkungan Kerja (X) berpengaruh dengan variabel Kinerja Karyawan (Y) sebesar 97,22\%.Uji Signifikan (uji t)/Hipotesis, berdasarkan hasil perhitungan uji hipotesis $t_{\text {hitung }} \geq \mathrm{t}_{\text {tabel }}$ maka Ho ditolak dan Ha diterima, $t_{\text {hitung }} \leq t_{\text {tabel }}$ maka Ho diterima dan Ha ditolak.
\end{abstract}

\section{Kata Kunci : Lingkungan Kerja Dan Kinerja Karyawan}




\section{PENDAHULUAN}

\section{Latar Belakang Masalah}

Manajemen sumber daya manusia merupakan bagian dari manajemen keorganisasian yang memfokuskan diri pada unsur sumber daya manusia. Tugas manajemen sumber daya manusia adalah mengelola unsur manusia secara baik agar diperoleh tenaga kerja yang puas akan pekerjaanya. Didalam organisasi, manusia merupakan salah satu unsur penting, karena manusia merupakan penggerak dan penentu jalanya kegiatan atau aktivitas perusahaan dalam mencapai tujuan baik untuk memperoleh keuntungan maupun untuk mempertahankan

kelangsungan hidup perusahaan. Berhasil atau tidak nya perusahaan dalam mempertahankan eksistensi perusahaan dimulai dari manusia itu sendiri dalam mempertahankan perusahaan dan dalam meningkatkan efektivitas dan efisiensi secara maksimal.

Manusia akan mampu melaksanakan kegiatan dengan baik, sehingga dicapai suatu hasil yang optimal, apabila diantaranya ditunjang oleh suatu kondisi lingkungan kerja yang sesuai, suatu kondisi lingkungan kerja dikatakan baiak atau sesuai apabila manusia dapat melaksanakan kegiatannya secara optimal, sehat, aman, dan nyaman.sebaliknya jika kondisi kerja yang buruk berpotensi menjadi penyebab karyawan mudah jatuh sakit, mudah stress, sulit berkonsentrasi, dan menurunya produktivitas kerja.

Suatu perusahaan dalam melaksanakan kegiatannya, baik perusahaan yang bergerak dibidang manufaktur, perdagangan maupun jasa akan berusaha untuk mencapai tujuan yang telah ditetapkan sebelumnya. Satu hal yang penting yaitu bahwa keberhasilan berbagai aktivitas didalam perusahaan dalam mencapai tujuan salah satunya adalah kenyaman lingkungan kerja. Kenyamanan lingkungan kerja karyawan dapat memicu karyawan untuk bekerja lebih baik sehingga produktivitas kerja dapat dicapai secara maksimal. Lingkungan kerja yang baik diharapkan dapat memacu kinerja kerja karyawan yang tinggi.Lingkungan kerja yang baik akan sangat besar pengaruhnya terhadap kinerja kerja karyawan, aspek yang berpengaruh terhadap lingkungan kerja antara lain pengaturan penerangan, tingkat kerja, kebisingan, sirkulasi udara yang baik terutama didalam lingkungan kerja, kebersihan lingkungan kerja, dan keamanan terhadap barang milik karyawan.

Perusahaan dengan kinerja yang tinggi akan terwujudnya apabila didukung oleh sumber daya manusia yang ada. Kinerja merupakan hasil kerja yangsebagai gambaran pekerjaan yang telah dilakukan di dalam organisasi. Pemahaman kinerja diarahkan kepada hasil kerja yang nyata dan jelas dari suatu organisasi. Banyak hal yang mempengaruhi kinerja karyawan di instansi, yang antara lain adalah lingkungan kerja yang kondusif, pengetahuan alat, sikap, perbaikan dan disiplin, tanggung jawab, motivasi kerja, kemampuan, keterampilan serta teknik-teknik manajerial.

Demikian juga PT Pos Indonesia merupakan sebuah badan 
usaha milik negara (BUMN) Indonesia yang bergerak di bidang layanan pos. Saat ini, bentuk badan usaha Pos Indonesia merupakan perseroan terbatas dan sering disebut dengan PT. Pos Indonesia

Akan tetapi keadaan lingkungan kerja pada PT Pos Indonesia yang kurang kondusif seperti : kurangnya pengadaan air condituoner (AC), Warna ruangan yang kurang menarik, penempatan meja yang masih perlu dilakukan perbaikan, serta hubungan kerja antar karyawan yang kurang harmonis menyebabkan ketidaknyamanan dalam bekerja. Maka hal ini harus lebih diperhatikan karena menyebabkan kurang optimalnya tingkat kinerja karyawan seperti loyalitas kerja dan menurumya disiplin kerja.

Berdasarkan latar belakang masalah diatas perlu dilakukan suatu penelitian untuk mengetahui "Pengaruh Lingkungan Kerja Terhadap Kinerja Karyawan Pada PT. Pos Indonesia di Depok".

\section{Identifikaasi Masalah}

Berdasarkan latar belakang tersebut diatas maka dapat diidentifikasi permasalahan sebagai berikut :

1. Kurangnya pengadaan air condituoner (AC), sehingga suhu udara tidak nyaman
2. Warna ruangan yang kurang menarik, sehingga suasana kerja tidak kondusif

3. Kurangnya ventilasi ruangan sehingga mempengaruhi suhu udara yg kurang baik.

4. hubungan kerja antar karyawan yang kurang harmonis menyebabkan ketidaknyamanan dalam bekerja

5. penataan/ lay out tata ruang kurang rapih sehingga lingkungan kerja tidak nyaman.

\section{Perumusan Masalah}

Berdasarkan identifikasi masalah diatas, maka penulis merumuskan masalah sebagai berikut :

1. Bagaimana kondisi lingkungan kerja pada PT Pos Indonesia di Depok?

2. Bagaiman kinerja karyawan pada PT Pos Indonesia di Depok ?

3. Bagaimana pengaruh lingkungan kerja terhadap kinerja karyawan pada PT Pos

Indonesia di Depok?

\section{Kerangka Berpikir}

Berdasarkan latar belakang dan permasalahan diatas terkait dengan pembinaan organisasi dan pegawai di PT Pos Indonesia, bahwa kinerja karyawan diasumsikan dapat ditingkatkan, apabila lingkungan kerja dapat dioptimalkan sehingga mampu meningkatkan kinerja karyawan sebagai upaya mewujudkan tercapainya tujuan organisasi. 
Kerangka pemikiran tersebut dapat dilihat pada gambar 2.1 dibawah ini

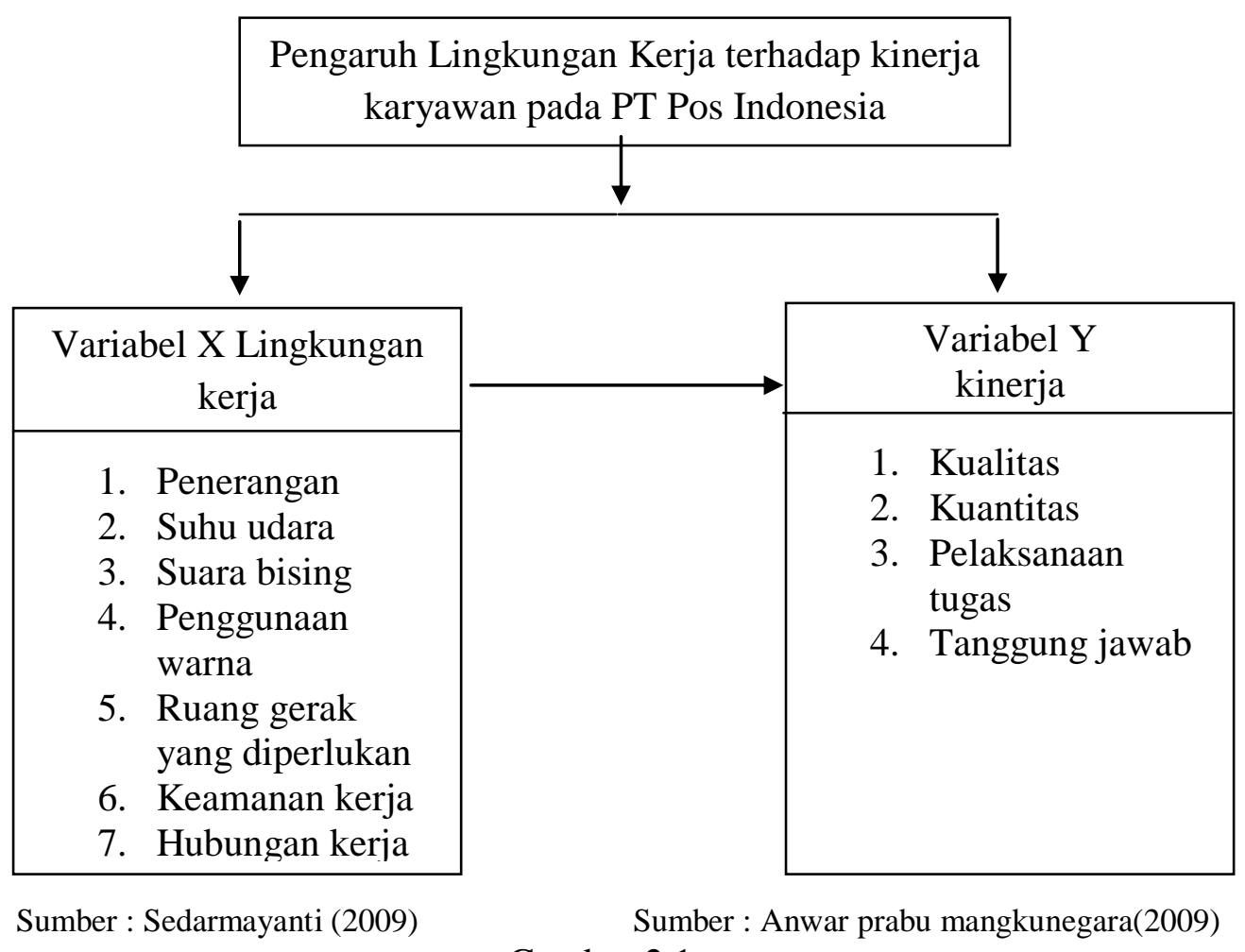

Gambar 2.1

Kerangka Berpikir

\section{TINJAUAN PUSTAKA}

\section{Lingkungan Kerja}

Ada beberapa pendapat mengenai lingkungan kerja internal dari beberapa ahli dibawah ini :

Menurut George $R$ Terry (2006:23) lingkungan kerja dapat diartrikan sebagai" kekuatankekuatan yang mempengaruhi, baik secara langsung maupun tidak langsung terhadap kinerja organisasi atau perusahaan".

Menurut Mardiana (2005) "Lingkungan kerja adalah lingkungan dimana karyawan melakukan pekerjaan nya sehari-hari “. Lingkungan kerja yang kondusif memberikan rasa aman dan memungkinkan para karyawan untuk dapat bekerja optimal. Lingkungan kerja dapat mempengaruhi emosi pegawai. Jika pegawai menyenangi lingkungan lingkungan kerja dimana dia bekerja, maka pegawai tersebut akan tetap tinggal ditempat dia bekerja untuk melakukan aktivitas sehingga waktu kerja dipergunakan secara efektif dan optimis prestasi kerja karyawan juga tinggi. Lingkungan kerja tersebut mencakup hubungan kerja yang berbentuk antara sesama karyawan dan hubungan kerja antar bawahan dan atasan serta lingkungan fisik tempat pegawai bekerja. 
Menurut Sedarmayanti (2009:130) menyebutkan bahwa "lingkungan kerja internal adalah keseluruhan alat perkakas dan bahan yang dihadapi, lingkungan kerja dimana seseorang bekerja, metode kerjanya serta pengaturan kerjanya baik sebagai perorangan maupun sebagai kelompok.

Menurut penulis dapat disimpulkn bahwa lingkungan kerja internal adalah tempat dimana karyawan bekerja yang didalamnya terdapat fasilitas-fasilitas yang menunjang karyawan dalam beraktivitas atau bekerja.

\section{Kinerja}

Kinerja adalah sebuah kata dalam bahasa Indonesia dasar "kerja" yang menterjemahkan dari bahasa asing yaitu prestasi, bisa pula yang berarti prestasi, bisa pula yang berarti hasil kerja.

Pengertian kinerja dalam organisasi merupakan jawaban dari berhasil atau tidaknya tujuan organisasi yang telah tetapkan para atasan atau manajer sering tidak memperhatikan kecuali sudah amat buruk atau segala sesuatu jadi serba salah.Terlalu sering manajer tidak mengetahui betapa buruknya kinerja merosot sehingga instansi menghadapi krisis yang serius, kesan-kesan buruk organisasi yang mendalam akibat tanda-tanda peringatan adanya kinerja yang merosot.

Adapun pengertian kinerja menurut beberapa ahli yaitu sebagai berikut : Kinerja sebagai hasil-hasil fungsi pekerjaan/kegiatan seseorang atau kelompok dalam suatu organisasi yang dipengaruhi oleh berbagai faktor untuk mencapai tujuan organisasi dalam periode waktu tertentu

(Payaman Simanjutak,2006).

Menurut Rivai dan Basri (2008) pengertian kinerja adalaah kesediaan seseorang atau kelompok orang untuk melakukan sesuatu kegiatan dan menyempurnakannya sesuai dengan tanggung jawab hasil seperti yang diharapkan.

Menurut Hasibuan Melayu (2007) kinerja merupakan perbandingan hasil kerja yang dicapai oleh karyawan dengan standar yang telah ditentukan.Seadangkan menurut Wibowo (2006) mendefinisikan kinerja sebagai hasil kerja yang dicapai oleh individu yang disesuaikan dengan peran atau tugas individu tersebut dalam suatu perusahaan pada suatu periode tertentu, yang dihubungkan dengan suatu ukuran nilai atau standar tertentu dari perusahaan dimana individ tersebut bekerja.

Kinerja merupakan perbandingan hasil kerja yang dicapai oleh pegawai. Selanjutnya Mangkunegara (2006:9), mengemukakan bahwa : "Kinerja karyawan (prestasi kerja) adalah hasil kerja secara kualitas dan kuantitas yang dicapai oleh seseorang krayawan dalam melaksanakan tugasnya sesuai dengan tanggung jawab yang diberikan kepadanya.

Menurut Veithzal Rivai (2008:309) mengemukakan kinerja adalah "merupakan perilaku yang nyata yang ditampilkan setiap orang sebagai prestasi kerja yang dihasilkan oleh karyawan sesuai dengan perannya dalam perusahaan".

Menurut Nawawi (2005:76) mengemukakan pendapatnya bahwa 
individu yang memiliki kinerja yang tinggi memiliki beberapa karakteristik, yaitu diantaranya "(a) berorientasi pada prestasi, (b) memiliki percaya diri, (c) berpengendalian diri, (d) kompetensi. Sedangkan menurut penulis Kinerja merupakan suatu kondisi yang harus diketahui dan dikonfirmasikan kepada pihak tertentu untuk mengetahui tingkat pencapaian hasil suatu instansi dihubungkan dengan visi yang diemban suatu organisasi atau perusahaan serta mengetahui dampak positif dan negative dari suatu kebijakan operasional

\section{METODOLOGI PENELITIAN}

Metode yang digunakan untuk penelitian ini adalah melalui study pustaka (Library Search) dan Study

\section{HASIL PENELITIAN DAN}

\section{PEMBAHASAN}

\section{A. Pembahasan Dan Hasil \\ Penelitian}

\section{Gambaran Umum Responden}

Berdasarkan data yang diperoleh dari penyebaran kuesioner pengaruh lingkungan kerja terhadap kinerja karyawan pada 56 responden yang bekerja pada PT. Pos Indonesia Depok adalah sebagai berikut :

\section{Tabel 4.1}

Responden Berdasarkan Jenis Kelamin

\begin{tabular}{|c|c|c|c|}
\hline No & Jenis Kelamin & $\begin{array}{c}\text { Jumlah } \\
\text { Orang }\end{array}$ & Presentase \\
\hline 1 & Pria & 35 & $62,50 \%$ \\
2 & Wanita & 21 & $37,50 \%$ \\
\hline & Jumlah & 56 & $100 \%$ \\
\hline
\end{tabular}

Sumber : Data di olah

Berdasarkan tabel di atas dapat dilihat, karyawan yang menjadi responden pada PT. Pos Indonesia
Lapangan (Field Search). Teknik pengumpulan data adalah bagian instrument pengumpulan data yang menentukan berhasil atau tidaknya suatu penelitian. Populasi dalam penelitian adalah seluruh karyawan PT Pos Indonesia Cabang Depok yang berjumlah 56 orang

Teknik pengambilan sampel pada penelitian ini adalah dengan menggunakan sampling jenuh yaitu teknik penentuan sampel bila semua anggota populasi digunakan sebagai sampel. Istilah lain sampel jenuh adalah sensus. Dalam hal ini penelitian menggunakan populasi sebagai sample semua. Sampel dalam penelitian ini berjumlah 56 orang yaitu seluruh karyawan PT Pos Indonesia Cabang Depok.

Depok adalah 35 Pria $(62,50 \%)$ dan 21 Wanita $(37,50 \%)$. Sehingga, dapat disimpulkan bahwa responden didominasi oleh jenis kelamin pria.

Tabel 4.2

Responden Berdasarkan Pendidikan

\begin{tabular}{|c|c|c|c|}
\hline No & Pendidikan & $\begin{array}{c}\text { Jumlah } \\
\text { Orang }\end{array}$ & Presentase \\
\hline 1 & SMP & 8 & $14,29 \%$ \\
2 & SMA/SMK & 18 & $32,14 \%$ \\
3 & SARJANA & 30 & $53,57 \%$ \\
\hline & Jumlah & 56 & $100 \%$ \\
\hline
\end{tabular}

Sumber : Data di olah

Berdasarkan tabel di atas dapat dilihat, presentase pendidikan responden pada PT. Pos Indeonesia Depok adalah SMP sebanyak 8 orang $\quad(14,29 \%), \quad$ SMA/SMK sebanyak 18 orang $(32,14 \%)$, dan Sarjana sebanyak 30 orang $(53,57 \%)$. Sehingga, dapat disimpulkan bahwa 
responden di dominasi oleh pendidikan Sarjana.

Tabel 4.3

Responden Berdasarkan Masa Kerja

\begin{tabular}{|c|c|c|c|}
\hline No & Masa Kerja & $\begin{array}{c}\text { Jumlah } \\
\text { Orang }\end{array}$ & Presentase \\
\hline 1 & $1-5$ tahun & 15 & $26,79 \%$ \\
2 & $5-10$ tahun & 29 & $51,78 \%$ \\
3 & $>10$ tahun & 12 & $21,43, \%$ \\
\hline & Jumlah & 56 & $100 \%$ \\
\hline
\end{tabular}

Sumber : Data di olah

Berdasarkan tabel di atas dapat dilihat, presentase masa kerja responden pada PT. Pos Indonesia Depok adalah 1-5 tahun sebanyak 15 orang $(26,79 \%), 5-10$ tahun sebanyak 29 orang $(51,78 \%)$, dan $>10$ tahun sebanyak 12 orang $(21,43 \%)$. Sehingga, dapat disimpulkan bahwa responden di dominasi oleh 5-10 tahun masa kerja.

\section{Uji Validitas}

Untuk menentukan valid atau tidaknya setiap butir pertanyaan variabel lingkungan kerja (X) dan kinerja karyawan (Y) maka dapat menghitungnya dengan menggunakan instrument validitas, berikut adalah rumus untuk menentukan validitas instrument dari setiap pertanyaan :

\section{a. Uji Validitas Instrumen $X$}

$r_{x i t}=\frac{n \sum X i X t-\left(\sum X i\right)\left(\sum X t\right)}{\sqrt{\left\{n \sum X i^{2}-\left(\sum X i\right)^{2}\right\}\left\{n \sum X t^{2}-\left(\sum X t\right)^{2}\right\}}}$

Dimana:

$\boldsymbol{r}=$ Nilai koefisien korelasi

$\boldsymbol{n}=$ Jumlah sampel (responden)

$\boldsymbol{X} \boldsymbol{i}=$ Skor setiap butir pernyataan
Tabel 4.4

Responden Berdasarkan Umur

\begin{tabular}{|c|c|c|c|}
\hline No & Umur & $\begin{array}{c}\text { Jumlah } \\
\text { Orang }\end{array}$ & Presentase \\
\hline 1 & $20-30$ tahun & 10 & $16,07 \%$ \\
2 & $30-40$ tahun & 28 & $51,78 \%$ \\
3 & $40-50$ tahun & 8 & $32,15 \%$ \\
4 & $>50$ tahun & & $0 \%$ \\
\hline & Jumlah & & $100 \%$ \\
\hline
\end{tabular}

Sumber : Data di olah

Berdasarkan tabel di atas dapat dilihat, presentase masa kerja responden pada PT. Pos Indonesia Depok adalah 20-30 tahun sebanyak 10 orang $(16,07 \%), 30-40$ tahun sebanyak 28 orang $(51,78 \%), 40-50$ tahun sebanyak 8 orang $(32,15 \%)$, dan $>50$ tahun sebanyak 0 orang $(0 \%)$. Sehingga, dapat disimpulkan bahwa responden di di dominasi oleh umur 30-40 tahun.

$\boldsymbol{X t}=$ Skor total butir seluruh pernyataan

Selanjutnya, nilai $\boldsymbol{r}_{\text {hitung }}$ dibandingkan dengan $\boldsymbol{r}_{\text {tabel }}$ pada tingkat alfa (taraf kesalahan) $5 \%$.

Kriteria keputusan:

$\boldsymbol{r}_{\text {hitung }} \geq \boldsymbol{r}_{\text {tabel }} \quad{ }_{(\alpha=5 \%)}, \quad$ maka instrumen (alat ukur) valid

$\boldsymbol{r}_{\text {hitung }}<\boldsymbol{r}_{\boldsymbol{t}\langle\text { bel }} \quad(\alpha=5 \%), \quad$ maka instrumen (alat ukur) tidak valid Dengan demikian, karena $\boldsymbol{r}_{\text {hitung }}$ hasil perhitungan lebih besar dari pada $\boldsymbol{r}_{\text {tabel }} \quad(0,643>0,263)$ sehingga disimpulkan bahwa butir pernyataan pada instrument No.1 variabel lingkungan kerja dapat dikatakan valid. Selanjutnya hasil perhitungan dari No.2 sampai 
No.10 saya jabarkan pada lembar lampiran.

Tabel 4.10 Hasil Analisis Item Instrumen

Lingkungan kerja

\begin{tabular}{|c|c|c|c|}
\hline $\begin{array}{c}\text { Butir } \\
\text { Pertanyaan }\end{array}$ & $\begin{array}{c}\text { r- } \\
\text { hitung }\end{array}$ & $\begin{array}{c}\text { r- } \\
\text { tabel }\end{array}$ & $\begin{array}{c}\text { Keteran } \\
\text { gan }\end{array}$ \\
\hline 1 & 0,644 & 0,263 & VALID \\
\hline 2 & 0,780 & 0,263 & VALID \\
\hline 3 & 0,737 & 0,263 & VALID \\
\hline 4 & 0,723 & 0,263 & VALID \\
\hline 5 & 0,757 & 0,263 & VALID \\
\hline 6 & 0,614 & 0,263 & VALID \\
\hline 7 & 0,777 & 0,263 & VALID \\
\hline 8 & 0,796 & 0,263 & VALID \\
\hline 9 & 0,760 & 0,263 & VALID \\
\hline 10 & 0,860 & 0,263 & VALID \\
\hline
\end{tabular}

Sumber: Data primer yang telah diolah 2016

Dari tabel rangkuman hasil perhitungan validitas instrumen pada variabel lingkungan kerja diatas dapat dilihat bahwa 10 butir pernyataan yang dijadikan sebagai instrumen pada variable lingkungan kerja dapat dikatakan valid, karena nilai $\boldsymbol{r}_{\text {hitung }}$ dari masing-masing butir pernyataan lebih besar daripada nilai $\boldsymbol{r}_{\text {tabel }}$ pada tingkat alfa (taraf kesalahan) 5\%, didapatkan nilai $\boldsymbol{r}_{\text {tabel }}$ sebesar 0,263

\section{b. Uji Validitas Instrumen $\mathbf{Y}$}

$r_{y i y t}=\frac{n \sum Y i Y t-\left(\sum Y i\right)\left(\sum Y t\right)}{\sqrt{\left\{n \sum Y i^{2}-\left(\sum Y i\right)^{2}\right\}\left\{n \sum Y t^{2}-\left(\sum Y t\right)^{2}\right\}}}$

Dimana:

$\boldsymbol{r}=$ Nilai koefisien korelasi

$\boldsymbol{n}=$ Jumlah sampel (responden)

$\boldsymbol{X} \boldsymbol{i}=$ Skor setiap butir pernyataan

$\boldsymbol{X} \boldsymbol{t}=$ Skor total butir seluruh pernyataan
Tabel 4.11 Tabel Uji Validitas

Variabel Y Kinerja karyawan

\begin{tabular}{|r|c|c|c|c|c|}
\hline \multicolumn{1}{|c|}{$\mathbf{N o}_{\mathbf{1}}$} & $\mathbf{Y}_{\mathbf{1}}$ & $\mathbf{Y}_{\mathbf{t}}$ & $\mathbf{Y}_{\mathbf{1}}{ }^{2}$ & $\mathbf{Y}_{\mathbf{t}}{ }^{2}$ & $\mathbf{Y}_{\mathbf{1}} \mathbf{Y}_{\mathbf{t}}$ \\
\hline 1 & 4 & 43 & 16 & 1849 & 172 \\
\hline 2 & 4 & 39 & 16 & 1521 & 156 \\
\hline 3 & 3 & 35 & 9 & 1225 & 105 \\
\hline 4 & 4 & 44 & 16 & 1936 & 176 \\
\hline 5 & 4 & 42 & 16 & 1764 & 168 \\
\hline 6 & 3 & 44 & 9 & 1936 & 132 \\
\hline 7 & 4 & 36 & 16 & 1296 & 144 \\
\hline 8 & 4 & 40 & 16 & 1600 & 160 \\
\hline 9 & 3 & 33 & 9 & 1089 & 99 \\
\hline 10 & 5 & 45 & 25 & 2025 & 225 \\
\hline 11 & 5 & 47 & 25 & 2209 & 235 \\
\hline 12 & 5 & 48 & 25 & 2304 & 240 \\
\hline 13 & 4 & 42 & 16 & 1764 & 168 \\
\hline 14 & 2 & 28 & 4 & 784 & 56 \\
\hline 15 & 4 & 41 & 16 & 1681 & 164 \\
\hline 16 & 5 & 48 & 25 & 2304 & 240 \\
\hline 17 & 3 & 39 & 9 & 1521 & 117 \\
\hline 18 & 5 & 40 & 25 & 1600 & 200 \\
\hline 19 & 3 & 32 & 9 & 1024 & 96 \\
\hline $\mathbf{N o}$ & $\mathbf{Y}_{\mathbf{1}}$ & $\mathbf{Y}_{\mathbf{t}}$ & $\mathbf{Y}_{\mathbf{1}}{ }^{2}$ & $\mathbf{Y}_{\mathbf{t}}{ }^{2}$ & $\mathbf{Y}_{\mathbf{1}} \mathbf{Y}_{\mathbf{t}}$ \\
\hline 20 & 5 & 44 & 25 & 1936 & 220 \\
\hline 21 & 5 & 41 & 25 & 1681 & 205 \\
\hline 22 & 5 & 48 & 25 & 2304 & 240 \\
\hline 23 & 4 & 47 & 16 & 2209 & 188 \\
\hline 24 & 4 & 44 & 16 & 1936 & 176 \\
\hline 25 & 2 & 28 & 4 & 784 & 56 \\
\hline 26 & 5 & 42 & 25 & 1764 & 210 \\
\hline 27 & 5 & 46 & 25 & 2116 & 230 \\
\hline 28 & 4 & 34 & 16 & 1156 & 136 \\
\hline 29 & 5 & 42 & 25 & 1764 & 210 \\
\hline 30 & 5 & 48 & 25 & 2304 & 240 \\
\hline 31 & 5 & 34 & 25 & 1156 & 170 \\
\hline 33 & 4 & 40 & 16 & 1600 & 160 \\
\hline 34 & 4 & 48 & 16 & 2304 & 192 \\
\hline 55 & 45 & 25 & 2025 & 225 \\
\hline
\end{tabular}




\begin{tabular}{|r|c|c|c|c|c|}
36 & 3 & 28 & 9 & 784 & 84 \\
\hline 37 & 4 & 37 & 16 & 1369 & 148 \\
\hline 38 & 3 & 44 & 9 & 1936 & 132 \\
\hline 39 & 5 & 47 & 25 & 2209 & 235 \\
\hline 40 & 4 & 33 & 16 & 1089 & 132 \\
\hline 41 & 5 & 39 & 25 & 1521 & 195 \\
\hline 42 & 5 & 46 & 25 & 2116 & 230 \\
\hline 43 & 3 & 35 & 9 & 1225 & 105 \\
\hline 44 & 5 & 50 & 25 & 2500 & 250 \\
\hline 45 & 4 & 40 & 16 & 1600 & 160 \\
\hline 46 & 4 & 44 & 16 & 1936 & 176 \\
\hline 47 & 4 & 44 & 16 & 1936 & 176 \\
\hline 48 & 5 & 49 & 25 & 2401 & 245 \\
\hline 49 & 3 & 43 & 9 & 1849 & 129 \\
\hline 50 & 3 & 35 & 9 & 1225 & 105 \\
\hline 51 & 4 & 45 & 16 & 2025 & 180 \\
\hline 52 & 5 & 42 & 25 & 1764 & 210 \\
\hline 53 & 3 & 36 & 9 & 1296 & 108 \\
\hline 54 & 4 & 41 & 16 & 1681 & 164 \\
\hline 55 & 4 & 40 & 16 & 1600 & 160 \\
\hline 56 & 4 & 35 & 16 & 1225 & 140 \\
\hline$\sum$ & 22 & 229 & & & \\
\hline & 9 & 975 & 96159 & 9571 \\
\hline$D i m a$ & & & & \\
\hline
\end{tabular}

Dengan demikian, karena $\boldsymbol{r}_{\text {㨭itung }}$ hasil perhitungan lebih besar dari pada $\boldsymbol{r}_{\text {tabel }}(0,648>0,263)$ sehingga disimpulkan bahwa butir pernyataan pada instrument No.1 variabel lingkungan kerja dapat dikatakan valid.

Tabel 4.12 Hasil Analisis Item Instrumen Kinerja karyawan

\begin{tabular}{|c|c|c|c|}
\hline $\begin{array}{c}\text { Butir } \\
\text { Pertanyaan }\end{array}$ & $\begin{array}{c}\text { r- } \\
\text { hitung }\end{array}$ & $\begin{array}{c}\text { r- } \\
\text { tabel }\end{array}$ & $\begin{array}{c}\text { Keteran } \\
\text { gan }\end{array}$ \\
\hline 1 & 0,648 & 0,263 & VALID \\
\hline 2 & 0,785 & 0,263 & VALID \\
\hline 3 & 0,731 & 0,263 & VALID \\
\hline 4 & 0,732 & 0,263 & VALID \\
\hline 5 & 0,758 & 0,263 & VALID \\
\hline 6 & 0,620 & 0,263 & VALID \\
\hline 7 & 0,770 & 0,263 & VALID \\
\hline 8 & 0,786 & 0,263 & VALID \\
\hline 9 & 0,753 & 0,263 & VALID \\
\hline 10 & 0,763 & 0,263 & VALID \\
\hline
\end{tabular}

Sumber: Data primer yang telah diolah 2016

Dari tabel rangkuman hasil

Dimana:

$\sum \mathrm{n} \quad \mathbf{5 6}$

$\sum \mathbf{Y i}^{2} \stackrel{\sum \mathbf{Y t}}{=\mathbf{9 7 5}}$

$\sum \mathbf{Y i}=229$

$=2299$

$=96159$

$=9571$

$=\frac{9505}{14657}$

$$
=0,648
$$

Selanjutnya,

nilair $\boldsymbol{r}_{\text {hitung }}$ dibandingkan

dengan $\boldsymbol{r}_{\boldsymbol{t}}$ <bel pada tingkat alfa (taraf kesalahan) $5 \%$.

Kriteria keputusan:

$\boldsymbol{r}_{\text {hitung }} \geq \boldsymbol{r}_{\text {tabel }} \quad(\alpha=5 \%), \quad$ maka instrumen (alat ukur) valid

$\boldsymbol{r}_{\text {hitung }}<\boldsymbol{r}_{\text {tabel }(\alpha=5 \%)}$, maka instrumen (alat ukur) tidak valid

$\sum \mathbf{Y t}^{2}$

$\sum$ Yi.Yt perhitungan validitas instrumen pada variabel kinerja karyawan diatas dapat dilihat bahwa 10 butir pernyataan yang dijadikan sebagai instrumen pada variabel kinerja karyawan dapat dikatakan valid, karena nilai $\boldsymbol{r}_{\text {hitung }}$ dari masingmasing butir pernyataan lebih besar daripada nilair $\boldsymbol{r}_{\text {tabel }}$ pada tingkat alfa (taraf kesalahan) 5\%, didapatkan nilai $\boldsymbol{r}_{\text {tabel }}$ sebesar 0,263

\section{Uji Reliabilitas}

Metode yang digunakan dalam penelitian ini untuk menghitung reliabilitas yaitu dengan menggunakan metode Cronbach Alpha. Dimana rumus yang digunakan adalah sebagai berrikut: 


$$
r_{c a}=\left(\frac{k}{k-1}\right)\left(1-\frac{\sum s_{i}}{s_{t}}\right)
$$

Dimana:

$\mathrm{r}_{\mathrm{ca}}=$ Nilai realibilitas instrument (Cronbach alpha) $\mathrm{S}_{\mathrm{i}} \quad=$ Varians skor tiap item pernyataan

$\mathrm{S}_{\mathrm{t}} \quad=$ Varians total

$\mathrm{k} \quad=$ Jumlah item pertanyaan Langkah-langkah mencari nilai
reliabilitas dengan metode Cronbach Alpha adalah sebagai berikut:

\section{a) Uji Reliabilitas Instrumen lingkungan kerja (X)}

1) Langkah 1: menghitung varian skor setiap pernyataan :

$\mathrm{Si}=\frac{\sum X i^{2}-\frac{\left(\sum X i\right)^{2}}{n}}{n}$

$\mathrm{S} 10=\frac{875-\frac{(217)^{2}}{56}}{56}=0,625$

2) Langkah 2 menghitung jumlah total varian semua butir pernyataan:

$\sum \mathrm{Si}=0,732+0,571+0,428+0,5+$ $0,714+0,517+0,642+0,625+$ $0,571+0,625=5.925$

3) Langkah 3 menghitung Varians total :

$\mathrm{St}=\frac{\sum X t^{2}-\frac{\left(\sum X t\right)^{2}}{n}}{n}$

$\mathrm{St}=\frac{1787}{56}$

$\mathrm{St}=31,91$

4) Langkah 4 menghitung nilai reliabilitas alpa :

rca $=\left(\frac{K}{K-1}\right)\left(1-\frac{\text { ós }}{s_{t}}\right)$

rca $=\left(\frac{10}{10-1}\right)\left(1-\frac{5,925}{31,91}\right)$

rca $=0,895$

Dengan

demikian, berdasarkan hasil perhitungan diatas diketahui bahwa $r_{c a}$ lebih besar dari $r_{\text {tabel }} \quad(0,895>0,263)$ sehingga instrumen penelitian dapat dikatakan reliabe

a. Uji Reliabilitas Instrumen kinerja karyawan $(Y)$

1) Langkah 1: menghitung varian skor setiap pernyataan :

$\mathrm{Si}=\frac{\sum X i^{2}-\frac{\left(\sum X i\right)^{2}}{n}}{n}$

$\mathrm{S} 1=\frac{975-\frac{(229)^{2}}{56}}{56}=0,696$

$\mathrm{S} 2=\frac{983-\frac{(251)^{2}}{56}}{56}=0,533$

$\mathrm{S} 3=\frac{961-\frac{(2299)^{2}}{56}}{56}=0,446$

$\mathrm{S} 4=\frac{1072-\frac{(972)^{2}}{56}}{56}=0,482$

S5 $=\frac{915-\frac{(221)^{2}}{56}}{56}=0,767$

S6 $=\frac{1029-\frac{(237)^{2}}{56}}{56}=0,464$

$\mathrm{S} 7=\frac{950-\frac{(226)^{2}}{56}}{56}=0,678$

$\mathrm{S} 8=\frac{987-\frac{(231)^{2}}{56}}{56}=0,625$

$\mathrm{S} 9=\frac{1021-\frac{(235)^{2}}{56}}{56}=0,625$

$\mathrm{S} 10=\frac{884-\frac{(218)^{2}}{56}}{56}=0,642$

2) Langkah 2 menghitung jumlah total varian semua butir pernyataan:

$\sum \mathrm{Si}=0,696+0,553+0,446+0,482$ $+0,767+0,464+0,678+0,625+$ $0,625+0,642=5,978$

3) Langkah 3 menghitung Varians total :

$\mathrm{St}=\frac{\sum X t^{2}-\frac{(\Sigma X t)^{2}}{n}}{n}$

$\mathrm{St}=\frac{1784}{56}$

St $=31,857 \Rightarrow 31,86$

4) Langkah 4 menghitung nilai reabilitas alpa :

rca $=\left(\frac{K}{K-1}\right)\left(1-\frac{\text { ós }}{s_{t}}\right)$ 
rca $=\left(\frac{10}{10-1}\right)\left(1-\frac{5,978}{31,86}\right)$

rca $=0,902$

Dengan demikian, berdasarkan hasil perhitungan diatas diketahui bahwa $\mathrm{r}_{\mathrm{ca}}$ lebih besar dari $\mathrm{r}_{\text {tabel }}(0,902>$ 0,263 ) sehingga instrumen penelitian dapat dikatakan reliabel.

1. Pengaruh Antara lingkungan kerja terhadap kinerja karyawan

a. Analisis Korelasi Sederhana Antara Variable $X$ Dengan Variabel Y

Dalam menganalisa hubugan variabel $\mathrm{X}$ terhadap variabel $\mathrm{Y}$ pada karyawan Kantor Pos, penulis menggunakan metode korelasi sederhana. Rumus yang digunakan untuk menghitung korelasi antara

Dimana:

$$
\begin{aligned}
& r x y=\frac{95724}{96994} \\
& r x y \\
& =0,986
\end{aligned}
$$

Berdasarkan hasil analisis diatas dengan menggunakan Korelasi Product Moment didapat nilai $r_{x y}$ sebesar 0,986 yang artinya terdapat hubungan positif yang sangat kuat antara lingkungan kerja terhadap kinerja karyawan kantor pos.

\section{b. Analisis Regresi Linier Sederhana}

Dalam penelitian ini analisis regresi bertujuan untuk mengetahui seberapa besar pengaruh lingkungan kerja terhadap kinerja karyawan depok .Salah satu model yang paling mudah untuk menjelaskan pengaruh itu adalah regresi sederhana, yaitu: $Y=a+b$ $\mathrm{X}$

Dimana rumusnya: variabel bebas $(\mathrm{X})$ dengan variabel terikat (Y) adalah Korelasi Product

\section{Moment.}

Dimana rumusnya sebagai berikut:

$$
\begin{aligned}
& \boldsymbol{r}_{x y} \\
& =\frac{n \sum X Y-\sum X \sum Y}{\sqrt{\left\{n \sum X^{2}-\left(\sum X\right)^{2}\right\}\left\{\left\{n \sum Y^{2}-\left(\sum Y\right)^{2}\right\}\right.}}
\end{aligned}
$$

Dimana:

$\boldsymbol{r}_{x y}=$ Nilai koefisien korelasi antara variabel bebas $(\boldsymbol{X})$ dengan variabel terikat $(\boldsymbol{Y})$

$\boldsymbol{n}=$ Jumlah sampel (Responden)

$\boldsymbol{X}=$ Variabel bebas (lingkungan kerja)

$\boldsymbol{Y}=$ Variabel terikat (Kinerja karyawan)

$$
\begin{aligned}
b & =\frac{n \sum \mathbf{x y}-\left(\sum \mathbf{x}\right)\left(\sum \mathbf{y}\right)}{n \sum \mathbf{x}^{2}-\left(\sum \mathbf{x}\right)} \\
a & =\frac{\sum \mathbf{y}}{\boldsymbol{n}}-\frac{b \sum \mathbf{x}}{\boldsymbol{n}}
\end{aligned}
$$

Dimana:

$\mathrm{n} \quad=$ Jumlah Sampel

$\mathrm{X}=$ Variabel Bebas (Pendidikan dan Pelatihan)

$\mathrm{Y}=$ Variabel Terikat (Kompetensi Kerja)

$$
\begin{aligned}
\sum X & =2299 \\
\sum Y & =2308 \\
\sum X^{2} & =96131 \\
\sum X Y & =96461
\end{aligned}
$$

$$
\begin{gathered}
\boldsymbol{b}=\frac{\boldsymbol{n} \sum \mathbf{x y}-\left(\sum \mathbf{x}\right)\left(\sum \mathbf{y}\right)}{\boldsymbol{n} \sum \mathrm{x}^{2}-\left(\sum \mathbf{x}\right)^{2}} \\
\boldsymbol{b}=\frac{56(96461)-(2299)(2308)}{56(96131)-(2299)^{2}} \\
\boldsymbol{b}=\frac{5401816-5306092}{5383336-5285401} \\
\boldsymbol{b}=\frac{95724}{97935}
\end{gathered}
$$

$\boldsymbol{b}=0,977$

$$
\boldsymbol{a}=\frac{\sum Y-\sum X}{n}
$$




$$
\begin{gathered}
\boldsymbol{a}=\frac{2308-0,977(2299)}{56} \\
\boldsymbol{a}=\frac{2308-2246}{56} \\
\boldsymbol{a}=1,107 \\
\hat{\mathrm{Y}}=\mathbf{1}, \mathbf{1 0 7}+(\mathbf{0 , 9 7 7}) \boldsymbol{X}
\end{gathered}
$$

Berdasarkan hasil perhitungan diatas dapat dijelaskan sebagai berikut:

1) Nilai konstanta intersep sebesar 1,107, merupakan konstanta (a). Menyatakan bahwa kalau $\mathrm{X}=0$, maka nilai $\mathrm{Y}=1,107$.

2) Nilai koefisien regresi variabel lingkungan kerja (X) terhadap kinerja karyawan (Y) adalah sebesar 0,977. Hal ini berarti jika lingkungan kerja (X) naik 1 satuan maka akan meningkatkan kinerja karyawan sebesar 0,977.

\section{c. Koefisien Determinasi (KD)}

Sedangkan untuk mengetahui besar presentase kontribusi antara lingkungan kerja terhadap kinerja karyawan pada kantor pos, diukur dengan koefisien determinasi atau koefisien penentu dengan rumus sebagai berikut :

$$
\begin{aligned}
\mathrm{KD} & =\mathrm{r}^{2} \times 100 \% \\
= & (0,986)^{2} \times 100 \% \\
= & (0,9722) \times 100 \% \\
= & 97,22 \%
\end{aligned}
$$

Nilai koefisien determinasi $\mathrm{KD}=$ $97,22 \%$ ini menunjukkan bahwa kontribusi variabel lingkungan kerja (X) berpengaruh dengan variabel kinerja karyawan (Y) sebesar $97,22 \%$, sedangkan selebihnya yaitu $(100 \%-97,22 \%)=2,78 \%$ dipengaruhi oleh faktor-faktor lain yang tidak diteliti penulis.

\section{d. Uji Hipotesis}

\section{1) Merumuskan hipotesis}

Adapun hipotesis yang diajukan dalam penelitian ini adalah sebagai berikut:

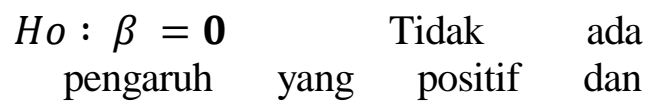

signifikan antara lingkungan kerja terhadap kinerja karyawan pada pt pos indonesia depok

$H a: \beta \neq 0$ Adanya pengaruh yang positif dan signifikan antara lingkungan kerja terhadap kinerja karyawan pada pt pos indonesia depok

\section{2) Uji Signifikasi}

Berdasarkan hasil perhitungan diatas, maka penulis melakukan pengujian hipotesa dengan cara membandingkan $t$ tabel dengan $t$ hitung. Nilai t tabel ditentukan berdasarkan tingkat signifikan yang digunakan dan derajat kebebasan yang besarnya tergantung dari jumlah sampel. Tingkat signifikan yang digunakan sebesar $5 \% \quad(0,05)$. Rumus $\mathrm{t}$ hitung adalah sebagai berikut :

$$
\begin{aligned}
& \boldsymbol{t}_{\text {hitung }}=\frac{\boldsymbol{r}_{\boldsymbol{x y}} \sqrt{\boldsymbol{n - 2}}}{\sqrt{\mathbf{1 - \boldsymbol { r } _ { x y } ^ { 2 }}}} \\
& =\frac{7,245}{0,16673} \\
& =43,45
\end{aligned}
$$

Nilai $t$ hitung selanjutnya dibandingkan dengan nilai $\mathrm{t}$ tabel dengan tingkat kesalahan 5\% dan derajat kebebasan 54 maka diperoleh $\mathrm{t}$ tabel sebesar 2,0048. Apabila $\mathrm{t}$ hitung $>\mathrm{t}$ tabel $\mathrm{H}_{1}$ diterima, atau dengan kata lain hubungan antara variabel pengaruh lingkungan kerja terjadap kinerja karyawan signifikan yaitu $43,45>2,0048$

\section{PENUTUP}

\section{Kesimpulan}

Berdasarkan hasil penelitian dan pembahasan yang telah dilakukan penulis dalam penelitian mengenai Pengaruh lingkungan kerja Terhadap kinerja karyawan Pada PT. Pos 
Indonesia di Depok, maka dapat disimpulkan sebagai berikut :

1. Lingkungan kerja pada PT. Pos Indonesia di Depok mendapat nilai baik, penulis menyimpulkan didasarkan pada hasil jawaban seluruh responden yang berjumlah 56 orang dengan 10 pernyataan yang menjawab "sangat setuju" sejumlah 195 (34,28\%), jawaban "setuju" sejumlah $250(44,64 \%)$.

2. Kinerja karyawan pada PT. Pos Indonesia di Depok adalah baik, berdasarkan pada hasil jawaban seluruh responden yang berjumlah 56 orang dengan 10 pernyataan yang menjawab "sangat setuju" sejumlah 193 (34,46\%), jawaban "setuju" sejumlah 525 (93,75\%).

3. Pengaruh lingkungan kerja terhadap kinerja karyawan berdasarkan perhitungan koefisien korelasi adalah sebesar 0,986 yang berarti pengaruh lingkungan kerja terhadap kinerja karyawan karyawan kuat kaitannya. Hal ini mengacu pada tabel 3.1.

Dari perhitungan regresi linier nilai $\mathrm{Y}=1,107+0,977 \mathrm{X}$ hal ini berarti jika lingkungan kerja $(\mathrm{X})$ naik 1 maka akan meningkatkan kinerja karyawan sebesar 0,977

Dari perhitungan koefisien determinasi (KD) diperoleh sebesar 97,22 \% hal ini menunjukan bahwa besarnya pengaruh lingkungan kerja terhadap kinerja karyawan adalah sebesar 97,22 \% sedangkan sisanya $(100 \%-97,22 \%)=2,78$ $\%$ di pengaruhi faktor lain.

Berdasarkan hasil pengujian rumus di atas maka $t$ hitung $>t$ tabel yaitu 43,45> 2,0048 dimana $\mathrm{H}_{0}$ ditolak $; \mathrm{H}_{1}$ diterima (signifikan) yang artinya lingkungan kerja $(\mathrm{X})$ terdapat pengaruh yang signifikan terhadap kinerja karyawan pada PT. Pos Indonesia di Depok.

\section{Saran}

Berdasarkan hasil analisis dan kesimpulan penelitian ini, maka ada beberapa temuan temuan yang dapat menjadi bahan saran bagi pihak - pihak terkait yaitu, sebagai berikut :

1. Dilihat dari variabel lingkungan kerja (X), bahwa indikator ruang gerak yang dibutuhkan mendapatkan respon yang paling rendah dari responden. Untuk itu disarankan manajer memperluas ruang kerja dikantor atau dapat juga menata ruang kerja dengan optimal.

2. Dalam variabel kinerja (Y) indikator kuantitas mendapatkan respon yang paling rendah dari responden. Untuk itu disarankan kinerja dikembangkan dengan cara memberikan motivasi kepada karyawan sehingga kuantitas yang dihasilkan dapat diperoleh secara optimal.”.

\section{DAFTAR PUSTAKA}

AA Prabu Mangkunegara, 2008 Manajemen Sumber Daya Manusia

Perusahaan.Remaja

Rosdakarya, Bandung

, tahun 2006, Perencanaan dan PengembanganManajemen

Sumber Daya Manusia, Pen. PT Refika Aditama

Anak Agung Ngurah Bagus Dhermawan, (2012), “jurnal pengaruh motivaasi lingkungan kerja,kompetisi, dan kompensasi terhadap kepuasan kerja dan kinerja 
pegawai di lingkungan kantor dinas pekerjaan umum provinsi bali", Universitas Udayana ISSN : 2098-0991

Aurelia Pot, (2013), “jurnal kepemimpinan, motivasi, dan lingkungan kerja pengaruhnya terhadap kinerja karyawan pada kanwil ditjen kekayaan negara suluttenggo dan maluku utara di manado", Universitas Sam Ratulangi Manado ISSN: 2303-1174

Daft, Richard L. 2003. Manajemen Sumber Daya Manusia. Jakarta:Penerbit Erlangga

Dessler, Gary. 2009. Manajemen SDM buku 1. Jakarta : Indeks

Dwi Agung Nugroho Arianto, (2013), "jurnal pengaruh kedisiplinan, lingkungan kerja dan budaya kerja terhadap kinerja tenaga pengajar" Universitas Islam Nahdlatul Ulama Jepara, indonesia ISSN: 2503-1637

Sugiono. "Metode Penelitian Kuantitatif Kualitatif dan $H \& D ”$, Alfabeta, Bandung, Cetakan ke-16, Agustus 2012

Handoko, Hani, "Metode-metode

Penelitian Kinerja",

Yogyakarta : BPFE

Yogyakarta, 2008

., "Manajemen Sumber Daya

Manusia", Edisi Revisi, Bumi

Aksara, Jakarta, Cetakan ke-7

Mei 2005
Juliansyah Noor,. "Metodelogi

Penelitian”, Jakarta : Kencana

Prenada Media Group, Cetakan ke-2 April 2012

Mohammad Nasir, "Metode

Penelitian", Jakarta : Ghalia

Indonesia, 1998

Veithza Rivai, 2004. Manajemen Sumber Daya Manusia Untuk Perusahaan. Jakarta: PT. Raja Grafindo Persada

Sedarmayanti. 2009. Sumber Daya Manusia dan Produktivitas Kerja.Bandung: CV Mandar Maju.

Suyadi Prawirosentono. (2008). Manajemen Sumber Daya ManusiaKebijakan

KinerjaKaryawan".

Yogyakarta:BPFE.

Terry, George R. dan Rue, Leslie W. 2005.Dasar-DasarManajemen Jakarta :Bumi Aksara.

\& Ahmad Fawzi Mohd Basri. 2005. Performance Appraisal Sistem YangTepat Untuk Menilai Kinerja Karyawan Dan Meningkatkan Daya Saing Perusahaan.. PT. Raja Grafindo Persada, Jakarta.

Zainul Hidayat, (2012), “Jurnal pengaruh lingkungan kerja dan disiplin kerja sertamotivasi kerja terhadap kinerja katyawan perusahaan derah air minum (PDAM)kabupaten lumajang”, STIE Widya Gama Lumajang ISSN :2088- 


\section{PANDUAN SINGKAT BAGI PENULIS JURNAL SDM JENIUS}

Panduan penulisan ini dimaksudkan untuk menyeragamkan bentuk penulisan karya ilmiah yang dikirim penulis ke redaksi Jurnal Jenius, dengan panduan penulisan sebagai berikut :

1. Naskah ditulis dalam Bahasa Indonesia dengan Abstrak Bahasa Indonesia dalam bentuk Font 12" dengan ukuran 1 Spasi dengan intisari tidak lebih dari 250 kata disertai 3 atau 4 kata kunci (keyword).

Naskah berupa Softcopy program MS maksimal 20 Halaman termasuk tabel dan gambar, spasi 1.

2. Sistematika penulisan disusun dengan urutan sebagai berikut :

a) Judul, nama dan alamat email penulis/peneliti tunggal.

b) Abstrak dan intisari, keyword dan kata kunci, dibuat dengan 1 kolom.

c) Batang Tubuh :

1). Pendahuluan, termasuk didalamnya intisari permasalahan

2). Perumusan Masalah

3). Tujuan Penelitian

4). Landasan teori termasuk didalamnya hipotesis dan kerangka Pemikiran

5). Metodologi Penelitian

6). Hasil dan Pembahasan

7). Kesimpulan

8). Daftar Pustaka

9). Seluruh isi tersebut di buat dengan 2 kolom

3. Judul ditulis dalam bentuk font Times New Roman 12" dengan huruf besar kecil dicetak tebal dan ditempatkan ditengah halaman,, serta tidak lebih dari 18 kata.

4. Tulisan karya ilmiah dalam bentuk font Times New Roman 12" dengan ukuran spasi 1,0 spasi dalam bentuk kolom.

5. Gambar diberi nomor dan keterangan, sedangkan tabel diberi nomor dan keterangan diatasnya.

6. Penulisan persamaan matematika yang terdapat pada halaman naskah hendaknya menggunakan equation editor.

7. Daftar pustaka hanya memuat literature yang dirujuk dalam keterangan dan dicantumkan pada bagian akhir naskah dilakukan dengan memberikan nomor.

8. Margin atas dan kiri $4 \mathrm{~cm}$, kanan dan bawah $3 \mathrm{~cm}$, dan ukuran kertas A4. 